DOI https://doi.org/10.30525/978-9934-26-111-4-64

\title{
ВИЗНАЧЕННЯ КРИТИЧНИХ ПЕРІОДІВ, ЯКІ МАКСИМАЛЬНО ВПЛИВАЮТЬ НА ВРОЖАЙНІСТЬ ШИШОК СОСНИ ЗВИЧАЙНОÏ (PINUS SYLVESTRIS L.), У ЛІВОБЕРЕЖНОМУ ЛІСОСТЕПУ УКРАЇНИ
}

\author{
Мажула О. С. \\ кандидат сільськогосподарських наук, \\ дочент кафедри прикладної біології, водних біоресурсів та \\ мисливського господарства \\ імені О. С. Тертишного \\ Харківська державна зооветеринарна академія
}

Бородін Ю. М.

кандидат сільськогосподарських наук, старший викладач кафедри прикладної біологї̈, водних біоресурсів та мисливського господарства

імені О. С. Тертишного

Харківська державна зооветеринарна академія

Авдєєв А. С.

старший викладач кафедри прикладної біологї̈, водних біоресурсів та мисливського господарства

імені О. С. Тертишного

Харківська державна зооветеринарна академія

м. Харків, Украӥна

Дослідження врожайності шишок у клонів плюсових дерев у Лівобережному лісостепу України у ДП «Зміївське ЛГ» проводились на трьох насінних плантаціях протягом 8-17 років. Аналіз багаторічних даних свідчить про індивідуальну репродуктивну поведінку різних клонів, яка $є$ результатом взаємодії генотипу рослини 3 оточуючим середовищем. В окремі роки загальні тенденції зміни врожайності на плантаціях, не пов'язані з віком та станом плантацій, переважали над індивідуальними, що свідчить про значний вплив критичних погодних умов на репродуктивні властивості дерев.

Кореляційний аналіз зв'язку між середньою урожайністю шишок у клонів сосни звичайної та кліматичними показниками травня у період 
«цвітіння» стробілів та літніх місяців за рік до «цвітіння» стробілів свідчать, що критичними температурними показниками, які суттєво вплинули на репродуктивні процеси у сосни звичайної були:

- середня температура у червні $\left(\mathrm{r} / \mathrm{t}_{\mathrm{r}}=-0,73 / 2,64\right)$;

- максимальна температура у червні $\left(\mathrm{r} / \mathrm{t}_{\mathrm{r}}=-0,73 / 2,65\right)$;

- середня температура у липні $\left(\mathrm{r} / \mathrm{t}_{\mathrm{r}}=-0,77 / 2,99\right)$;

- максимальна температура у липні $\left(\mathrm{r} / \mathrm{t}_{\mathrm{r}}=-0,85 / 3,92\right)$;

- абсолютний максимум у липні $\left(\mathrm{r} / \mathrm{t}_{\mathrm{r}}=-0,91 / 5,32\right)$;

- кількість опадів у серпні $\left(\mathrm{r} / \mathrm{t}_{\mathrm{r}}=0,81 / 3,37\right)$;

- середньомісячний дефіцит вологості у червні $\left(\mathrm{r} / \mathrm{t}_{\mathrm{r}}=-0,83 / 3,60\right)$;

- максимальний дефіцит вологості у червні $\left(\mathrm{r} / \mathrm{t}_{\mathrm{r}}=-0,82 / 3,49\right)$;

- абсолютний максимум дефіциту вологості у червні $\left(\mathrm{r} / \mathrm{t}_{\mathrm{r}}=\right.$ $0,82 / 3,52)$

- максимальний дефіцит вологості у липні $\left(\mathrm{r} / \mathrm{t}_{\mathrm{r}}=-0,85 / 4,01\right)$;

- абсолютний максимум дефіциту вологості у липні $\left(\mathrm{r} / \mathrm{t}_{\mathrm{r}}=-\right.$ $0,84 / 3,79)$.

Уточнення критичних періодів, які вплинули на закладання жіночих стробілів показало наявність наступних зв'язків. Найбільші кореляційні залежності виявлені між урожайністю шишок та:

- середньою температурою у другій декаді червня $\left(\mathrm{r} / \mathrm{t}_{\mathrm{r}}=-0,82 / 3,55\right)$;

- максимальною температурою у другій декаді червня $\left(\mathrm{r} / \mathrm{t}_{\mathrm{r}}=\right.$ $0,85 / 4,01)$;

- максимальною температурою у третій декаді липня $\left(\mathrm{r} / \mathrm{t}_{\mathrm{r}}=-\right.$ $0,80 / 3,26)$;

- середнім дефіцитом вологості у другій декаді червня $\left(\mathrm{r} / \mathrm{t}_{\mathrm{r}}=\right.$ $0,86 / 4,11)$;

- максимальним дефіцитом вологості у другій декаді червня $\left(\mathrm{r} / \mathrm{t}_{\mathrm{r}}=\right.$ $0,86 / 4,16)$;

- середнім дефіцитом вологості у третій декаді липня $\left(\mathrm{r} / \mathrm{t}_{\mathrm{r}}=\right.$ $0,78 / 3,06)$;

- максимальним дефіцитом вологості у третій декаді липня $\left(\mathrm{r} / \mathrm{t}_{\mathrm{r}}=-\right.$ $0,84 / 3,78)$.

Кореляції між кліматичними показниками першої та третьої декади червня, першої та другої декади липня, а також трьома декадами серпня та врожайністю шишок не виявлено.

На основі вказаних кліматичних показників року закладання жіночих стробілів можливо 3 високою ймовірністю прогнозувати рівень врожайності шишок сосни звичайної через 2 роки та робити відповідні запаси насіння перед неврожайними роками. Для кожного лісонасінного району ці показники слід уточнювати. 